\title{
INFLUENCE OF EDTACAL SPOFA APPLICATION ON SOME BIOCHEMICAL AND HEMATOLOGICAL PARAMETERS IN SHEEP BLOOD
}

\author{
J. STRKİŽ, P. JAGOŠ and L. POKORNÝ \\ Department of Diagnosis, Therapy and Control of Animal Diseases, \\ University of Veterinary Science, 61242 Brno \\ Received fanuary 4, 1984
}

\begin{abstract}
Stříž, J., Jagoš, P., Pokorný, L.: Influence of EDTACAL Spofa Application on Some Biochemical and Hematological Parameters in Sheep Blood. Acta vet. Brno, 54, 1985: 61-71.

In five clinically healthy sheep of the Caucasian merino breed the effect of EDTACAL Spofa application at the dose of $40 \mathrm{mg} \cdot \mathrm{kg}^{-1}$ of the live body mass, applied i.v. once daily in the duration of 5 days, upon the values of 23 biochemical and hematological parameters in blood has been followed. The EDTACAL treatment induced a marked $(P<0.05-<0.01)$ increase of the values of urea, glucose, magnesium (even from the initially hypomagnesiemic levels), blood $\mathrm{pH}, \mathrm{BE}, \mathrm{SB}$, $\mathrm{BB}$, and on the other hand a marked decrease was seen of the zinc levels (down to the subnormal level), copper, leukocyte count, GMT activity. Moreover, statistically insignificant rise of sodium, potassium, inorganic phosphorus, $\mathrm{Hb}, \%$ of methemoglobin levels and an insignificant fall of calcium, cholesterol, hematocrit, erythrocyte count, AST activity and later even of sodium level was found. The increase of $\mathrm{pCO}_{2}$ values was almost undetectable; insignificant changes were found in the total protein. Following the application of the preparation the values of urea, sodium, magnesium, zinc, copper, $\mathrm{pH}$ of blood, GMT activity and of leukocyte count were observed to increase already after 24 hours and of $\mathrm{pCO}_{2}, \mathrm{BE}, \mathrm{SB}$ and $\mathrm{BB}$ after two days. The increase in $\mathrm{Hb}$ and glucose levels was found after 3 and 4 days, resp. The AST activity decreased only after the cessation of the application. The return to the initial values appeared in most parameters, being established gradually within 2 to 5 days following the cessation of the preparation administration; only the changes in GMT, blood $\mathrm{pH}$ and leukocyte count were observed to outlast for further 5 days. The effect of EDTACAL upon the acid-base balance was found to be alkalogenic. EDTACAL also stabilized some parameters by decreasing the individual daily variations (urea, sodium, calcium, magnesium, zinc, copper, hemoglobin, erythrocytes, leukocytes), and levelled also the differences between individual animals (urea, glucose, sodium, calcium, zinc, erythrocytes and leukocytes). The EDTACAL influence during its application was thus manifested by a broader interference with various metabolic processes in the experimental animal.
\end{abstract}

Sheep, total protein, urea, glucose, macroelements, microelements, AST and GMT activities, cholesterol, acid-base parameters, methemoglobin.

Ethylenediaminetetraacetic acid (EDTA) and its salts are characterized by specific chelating properties. They have a high affinity towards some substances, particularly to some elements and their compounds, readily forming bonds and complexes of a varying strength. This property has been employed in laboratories, in experimental, diagnostical or even in therapeutical methods, e.g. in toxicology in cases of heavy metal poisoning the application of EDTA leads to complexation of noxae thus making possible their excretion from the organism. It could, nevertheless, be assumed that apart from this effect also some other components of metabolically important substances, such as enzymes, hormones or vitamins, could also be bonded. This will take place preferably in blood and extracellular fluids. Secondarily, the cellular components may be involved, thus influencing 
the formation, biological activity etc. of these substances. The application of EDTA can thus influence various systems in the organism, both by direct effect and through various correlation relations.

In order to elucidate the effect of EDTA application to an animal organism we have, in this connection, followed basic biochemical and hematological parameters in the blood of experimental animals. Examination of these parameters is included into the system of currently used metabolic test for farm animals.

Apart from industrial and laboratory techniques and chemistry, the EDTA and its salts and analogues find their application also in experimental medicine and biology where they serve for an aimed induction of deficiency conditions of metal elements. Further application is seen in therapy where, since its introduction in 1953, the EDTA has been used to treat heavy metal poisonings. An acute hypocalcemia following the EDTA application is generally known. A salt, already containing calcium $\left(\mathrm{CaNa}_{2} \mathrm{EDTA}\right)$, is thus used to treat this condition. Following this treatment, the increase of $\mathrm{K}$ and $\mathrm{Mg}$ concentration in the blood of cattle and sheep (Daniel 1980), the decrease of $\mathrm{Cu}$ in liver (Soeli et al. 1974), in blood, tissues and other organs, the increase of EDTA excretion, the lowering of $\mathrm{Zn}$ content in an organism (Kratzer 1974 and others), a lowered Fe availability in fowl (Christopher et al. 1974) have been observed. The change in the activity of various enzymes and hormones, e.g. of parathormone (Scott and Beastall 1978) and the influence upon some vitamins have also been reported. The EDTA increased the fowl resistance agains salmonella infection, propably due to the bonding of bacterial Fe (Hill and Smith 1974), etc. The observed results are, nevertheless, often controversial. Zinc may serve as a typical example of elements that are easily complexed by EDTA (Lantzsch and Menke 1974; Peters 1974 and others). As zinc is a component of many important enzymes and serves as an activator of many others, especially in the groups of peptidases, dehydrogenases, oxidases etc., a pronounced effect of EDTA on the above mentioned enzymes should be expected as a result of influence on $\mathrm{Zn}$. Roth and $\mathrm{Kirch}-$ gessner (1974) have indeed observed a decrease in carboanhydrase activity following the bonding of $\mathrm{Zn}$ by EDTA, Reinhold et al. (1969) and Kirchgessner and Roth (1975) found the same effect in phytase and ALP and in other Zn-related enzymes, resp. On the other hand, Špak (1976) as well as Burch et al. (1974) have observed no decrease in carbohydrase and other enzymes, resp., in spite of the fall of $\mathrm{Zn}$. As to the bonding capactiy of the EDTA, different data have been reported. Hauschild (1961) in his review on EDTA "komplexkonstants" (i.e. the coefficient of element bonding) presents $\log \mathrm{K}=16.1$ and 18.3 for $\mathrm{Zn}$ and $\mathrm{Cu}$, resp. Lantzsch and Menke (1974) estimate, however, this EDTA bonding capacity for $\mathrm{Zn}$ to be only $2 \%$. Zinc was, nevertheless, found to be complexed more intensely than copper (Kleavy 1974). The therapeutical application of EDTA has been generally recommended for treatment of heavy metal poisonings in human medicine; Bartík and Piskač (1974) recommended its application also in veterinary medicine, particularly in cases of lead poisoning. Vodrážka et al. (1980), however, do not recommend the use of EDTA for this purpose.

The reasons for different experimental and therapeutical results are probably multifactorial. There are already many differences in dosage and mode of administration of EDTA. The recommended doses of the EDTA are differing: $75 \mathrm{mg} \cdot \mathrm{kg}^{-1}$ of the live body mass/day for humans (Hauschild 1961), $75 \mathrm{mg} . \mathrm{kg}^{-1}$ of the live body mass for sheep (Hiepe 1970) in the duration of 3--4 days, $20-40 \mathrm{ml}$ for cows, i.e. $8-16 \mathrm{mg} \mathrm{kg}^{-1}$ of the live body mass (G dovin et al. 1970), approximately $20 \mathrm{mg} \cdot \mathrm{kg}^{-1}$ of the live body mass every fourth day for animals (Bartík and Piskac 1974), $110 \mathrm{mg} \cdot \mathrm{kg}^{-1}$ of the live body mass every 12 hours during 2 days for sheep (Soeli 1974). The dose reported by Wenke, Hynek and Mráz (1977) for men is only $13.3 \mathrm{mg} . \mathrm{kg}^{-1}$ of the live body mass. According to the producer of the EDTACAL Spofa preparation the dose for men should be $26 \mathrm{mg} . \mathrm{kg}^{-1}$ of the live body mass, the treatment being repeated $8-10$ times, every third day.

\section{Materials and Methods}

Five sheep of the Caucasian merino breed, $2-3$ years old were used for experiments. The animals were in average or inferior nutrition condition, their live body mass ranging from 34 to $63 \mathrm{~kg}$; they were neither pregnant nor lactating. Permanent feed ratio consisted of meadow hay ad lib. and of $0.30 \mathrm{~kg}$ of crushed oats per animal and day. No clinical signs of disease were apparent. Blood samples from v. jugularis were taken daily at $7 \mathrm{a} . \mathrm{m}$. for 15 days. Altogether 23 parameters were followed. They included levels of total protein, urea, glucose, sodium, potassium, calcium, magnesium, inorganic phosphorus, zinc, copper, cholesterol, AST and GMT activities. Acid-base balance (blood $\mathrm{pH}, \mathrm{pCO}_{2}, \mathrm{BE}, \mathrm{SB}, \mathrm{BB}$ ) and some hematological values $(\mathrm{Hb}$, hematocrit, erythrocyte and leukocyte count) and methemoglobin $\%$ in $\mathrm{Hb}$ were also examined. At the same time the general health condition, appetite and possible reactions to preparation application were also observed. EDTACAL Spofa, i.e. a $20 \%$ solution of dinatrium calcii edetici (aethylendiaminotetraacetici) 
was used. The application started from the fifth day immediately after the blood sampling, intravenously in the dose of $40 \mathrm{mg} \cdot \mathrm{kg}^{-1}$ of the live body mass daily for 5 days.

\section{Results}

EDTACAL influenced a number of the followed parameters. A significant increase in values was found in the case of urea, glucose, $\mathrm{Mg}$, blood $\mathrm{pH}, \mathrm{BE}, \mathrm{SB}, \mathrm{BB}$; on the other hand the decrease was observed in $\mathrm{Zn}, \mathrm{Cu}, \mathrm{Na}$ levels, GMT activity and in leukocyte count. The lowering of the values of $\mathrm{Ca}$, cholesterol, hematocrit and erythrocyte count as well as the increase of $\mathrm{Hb}, \mathrm{P}$ inorg., $\mathrm{K}$ and hemoglobin percent were not of statistical significance. The increase of $\mathrm{pCO}_{2}$ value and the decrease of AST activity were found to be within the detection limits. The levels of total protein remained essentially without a marked effect.

Already one day after the EDTACAL administration the level of urea increased from subnormal values to physiological range and continued to remain there till the 1st day after the cessation of administration. The increase of the glucose level (from subnormal values as well) appeared on the 5th day of application, the return to hypoglycaemia appearing again 3 days after the end of administration. Two different tendencies can be observed from the course of level changes, i.e. the increase during the application and a marked decrease persisting for 5 days after the end of administration. The $\mathrm{Mg}$ levels rised from hypomagnesiemic to normal values and then decreased always one day after the commencing and ending of administration, resp. The decrease of $\mathrm{Zn}$ level from the initial relatively high values to subnormal was observed. In the same time interval a similar tendency was observed in the case of copper but the changes did not exceed physiological range. The $\mathrm{Zn}: \mathrm{Cu}$ ratio changed, however, significantly from $1.18: 1$ to $0.79: 1$. The AST activity was found to decrease slightly after the end of administration, that of GMT was evidently lower during and after the whole application. The rise in blood $\mathrm{pH}$, exceeding the upper physiological limit, appeared also whithin 24 hours after the onset of treatment; it did not change after the end of administration. A similar tendency, i.e. the increase with two peaks after 4 and 7 days and the decrease after the end of application, has been observed in $\mathrm{pCO}_{2}$, $\mathrm{BE}, \mathrm{SB}$ and BB values. The $\mathrm{Hb}$ level, after the initial drop, increased after 4 days following the onset of administration from subnormal to physiological ranges, remaining there for further 5 days. As early as in the 1st day after the treatment the leukocyte count dropped and remained near the lower physiological limit.

In many parameters a diminution in individual daily variations (urea, $\mathrm{Na}, \mathrm{Ca}, \mathrm{Mg}$, $\mathrm{Zn}, \mathrm{Cu}, \mathrm{Hb}$, erythrocytes, leukocytes) and possibly of their mutual differences among individual experimental animals (urea, glucose, $\mathrm{Na}, \mathrm{Ca}, \mathrm{Zn}$, erythrocytes and leukocytes) could be observed during the EDTACAL treatment or after it, as it follows from lower values of standard deviations.

No unfavourable reactions or clinical signs health condition disturbances were observed in animals during the experiment.

\section{Discussion}

The results of our experiment show that the effect of EDTACAL interferes with metabolism of experimental animals. It is documented by changes in basic parameters such as glucose and urea, changes in leukocyte count, in the enzyme activity, etc., mechanisms of each effect being probably quite different. The glucose increase could 


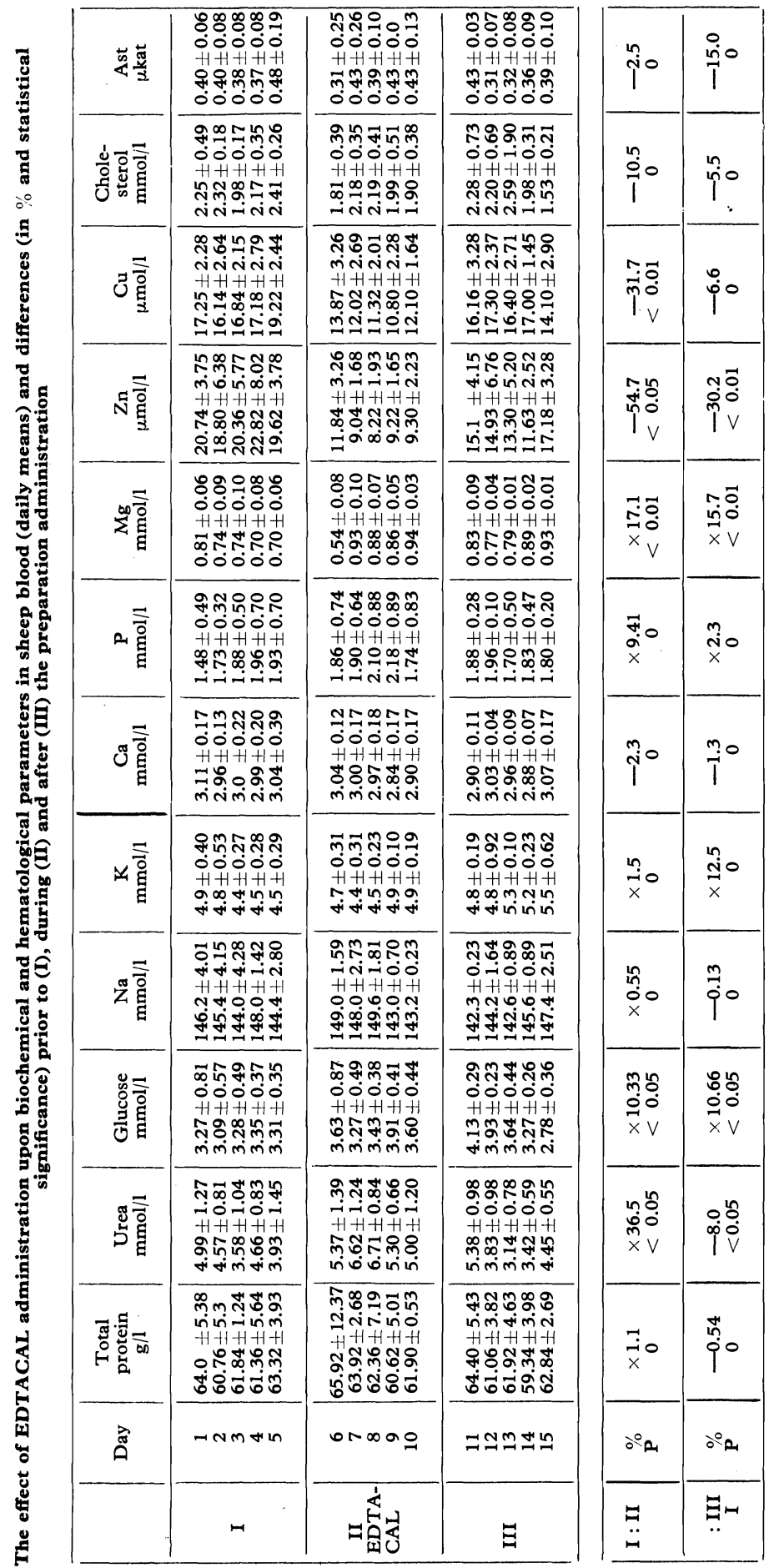




\begin{tabular}{|c|c|c|c|c|c|}
\hline 떰홍 & 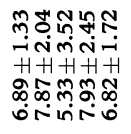 & 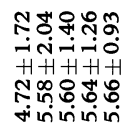 & 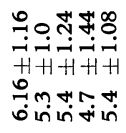 & חึ่o & 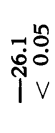 \\
\hline 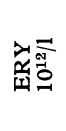 & 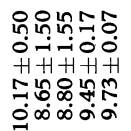 & 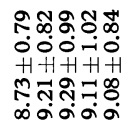 & 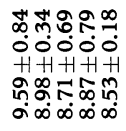 & $\vec{p} 0$ & స \\
\hline 荤三 & 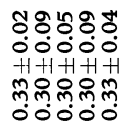 & 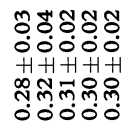 & 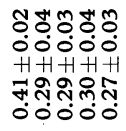 & $\tilde{p}^{m} 0$ & ن̊ \\
\hline 䍃 & 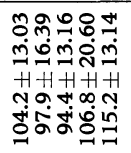 & 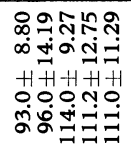 & 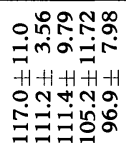 & $\stackrel{\substack{n \\
\dot{x}}}{0}$ & $\stackrel{\substack{n \\
+\\
x}}{x}$ \\
\hline$\sum_{\Sigma}^{\infty}$ & 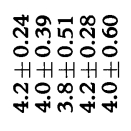 & 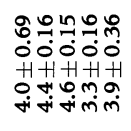 & 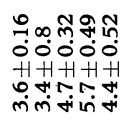 & $\stackrel{0}{\rightarrow 0}$ & $\stackrel{\circ}{\circ} \mathrm{i} 0$ \\
\hline 䑰 & 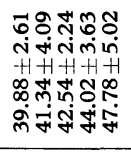 & 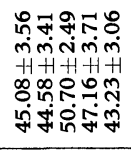 & 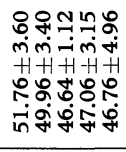 & $\stackrel{\text { ㅅ}}{x}$ & 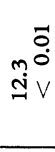 \\
\hline ๘ & 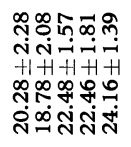 & 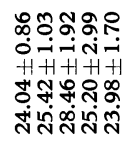 & 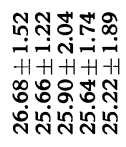 & $\begin{array}{l}\circ 0 \\
\infty \\
\infty \\
\times \\
\times\end{array}$ & 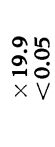 \\
\hline 岗 & 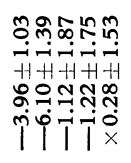 & 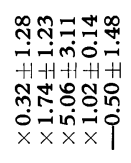 & 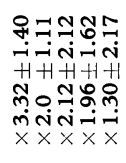 & $\begin{array}{l}\text { ○ंठ } \\
\text { ஸें } \\
\text { IV }\end{array}$ & $\begin{array}{l}\text { no } \\
\stackrel{0}{0} 0^{\circ} \\
\times \\
\times V\end{array}$ \\
\hline 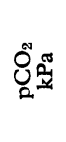 & 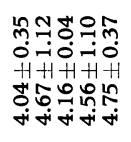 & 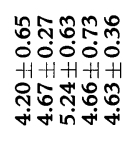 & 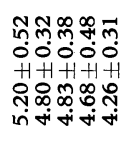 & $\begin{array}{l}\text { Ņo } \\
\text { ம. }\end{array}$ & $\stackrel{\circ}{\infty} \underset{\times}{\infty}$ \\
\hline 要 & 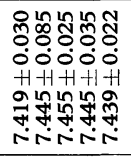 & 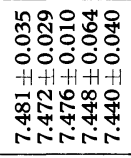 & 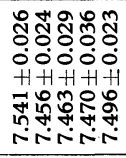 & 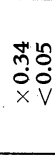 & 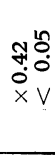 \\
\hline 㫐葋 & 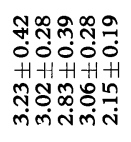 & 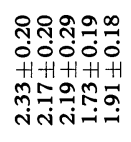 & 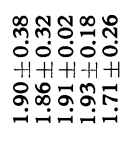 & 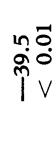 & भก. \\
\hline \multirow[t]{2}{*}{$\overrightarrow{\nexists ~}$} & TNMtrin & orma으 & ニエツざ & $\therefore$ & $\therefore P^{\prime}$ \\
\hline & - & 画四 & $\Xi$ & $\exists$ & 洁 \\
\hline
\end{tabular}



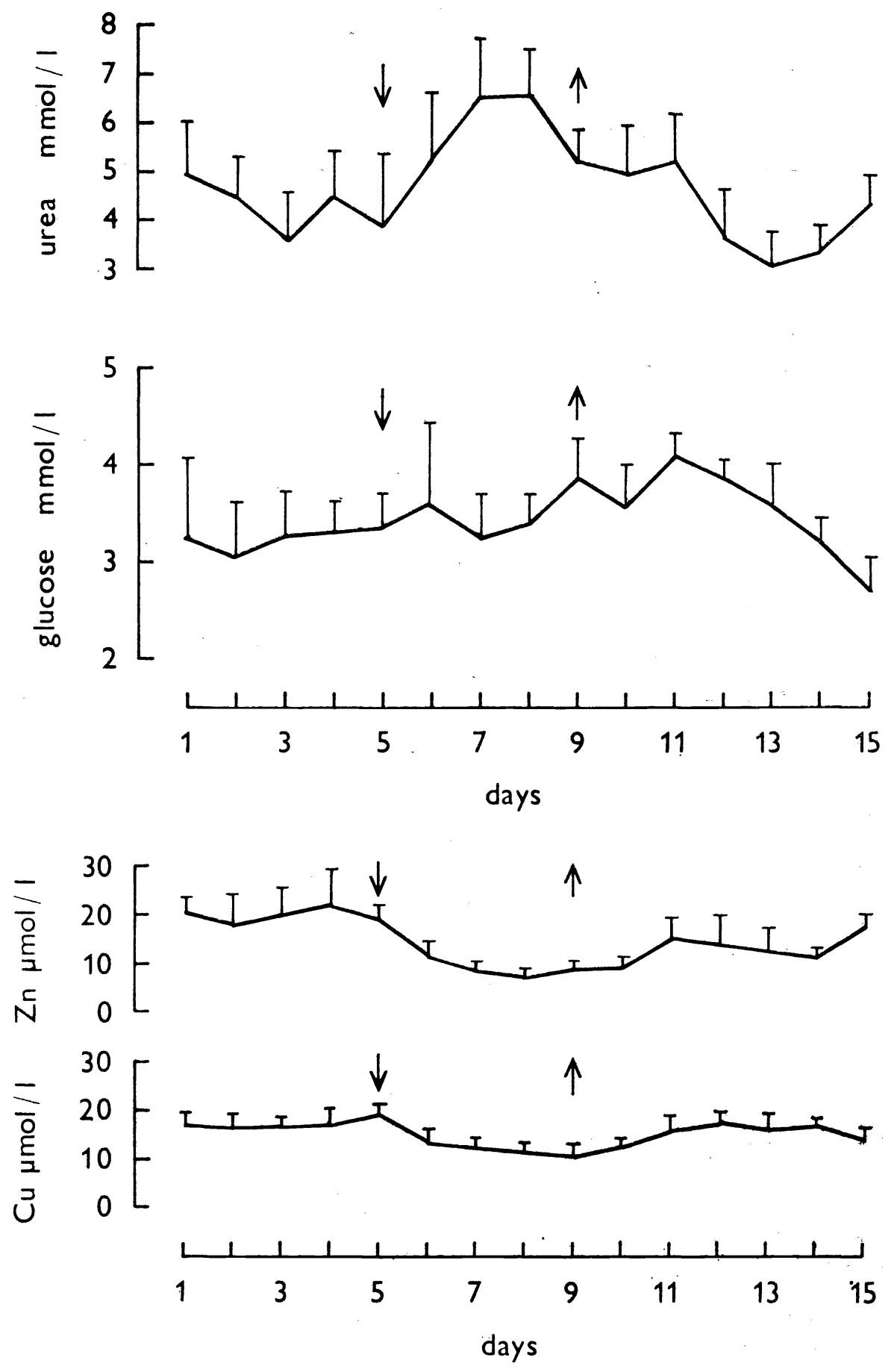

Fig. 1

Dynamics of blood glucose and urea in sheep before, during and after the administration of Edtacal Spofa. The beginning and termination of therapy indicated by arrows. 

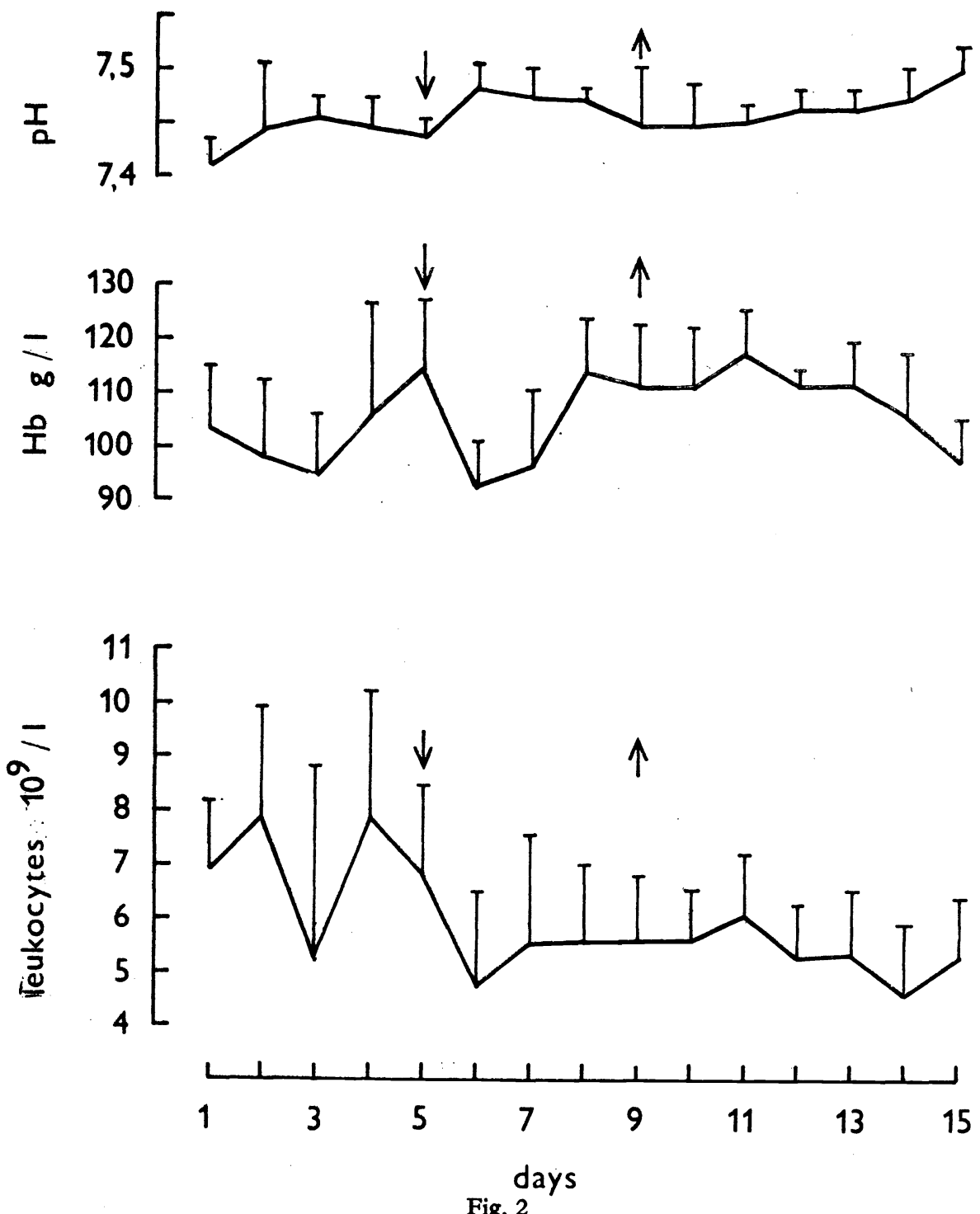

Dynamics of leukocyte counts, hemoglobin and pH of blood in sheep before, during and after the administration of Edtacal Spofa. For legend see Fig. 1.

be ascribed either to the improvement in its resorption or formation with the enhanced glycogenolysis or to the general changes in the formation and release of glycogen, lowered glucose availability in target organs, etc. Most probably it is a consequence of interference with an enzymatic system and possibly with a regulation system, hormonally controlled. So, e.g. the case of the insulin shortage may be accounted for by $\mathrm{Zn}$ deficiency. The increase of urea levels may stem from many reasons ranging from the improvement of its synthesis in liver over the increased protein degradation to the impaired excretion by kidneys (EDTA exerts a higher load also on kidneys). 
Also the changes in Na levels could be multifactorial. The increased supply of $\mathrm{Na}$ contained in the preparation (sodium salt) with consequent homeostatic regulation processes, the influence of $\mathrm{Ca}$, which reportedly replaces $\mathrm{Na}$ in tissue colloids and enhances its excretion thus decreasing also the Na levels in blood (Ha uschild 1961). The Na losses in form of complexes with other elements could also be responsible for the initial rise and later marked fall of $\mathrm{Na}$. Considering the relations between $\mathrm{Na}$ and $\mathrm{K}$, changes in $\mathrm{K}$ level could also be expected. These changes were not, however, unequivocally proven although e.g. Daniel (1980) reports on the increase of $\mathrm{K}$ after the EDTA application in cattle and sheep. In our experiment the observed increase of $\mathrm{Mg}$ level corresponded to results obtained by Reitz and Weinstein (1974) in men and by Daniel (1980) in cattle and sheep. The strong decrease of $\mathrm{Zn}$ was also in accordance with the results published elsewhere. The speed and the extent of this decrease, creating an impression of a selective trapping of this element, could be due to its relative low pool in the organism, by less strong bonds to vector of mostly protein character, by negative influence of calcium from EDTACAL or even of copper. The concentration decrease of $\mathrm{Cu}$ was substantially less pronounced, thus inducing an unfavourable condition for zinc and vice versa (Pories et al. 1974). The final consequence of this was manifested by the lowering of the $\mathrm{Zn}: \mathrm{Cu}$ ratio. We have not confirmed the results of Kleavy (1974) who observed, at this low ratio, even the influence upon cholesterol. If plasma $\mathrm{Cu}$, bonded to albumin (ca $10 \%$ ) or to globulins (22\%) or to aminoacids, disappears in a greater extent there is probably a dependence on the bond strengths, this being applicable also to $\mathrm{Zn}$. In the case of zinc, $66 \%$ is bonded to albumin and $22 \%$ to globulins, mostly to alpha macroglobulin. We have not examined these circumstances and the degree of element mobilization from the stores. The decrease of the AST and GMT activity could be explained by their direct impairment, either primarily or through correlation relations. Their limited release from cells, particularly from hepatic ones, could also occur, thus indicating a certain protective effect of EDTA upon liver. When this preparation is, however, administered, the influence upon metalloenzymes and to a greater extent upon their co-enzymes and activators, in which the metals are less strongly bonded, the metal complexing being thus easier, could be expected. The EDTACAL was found to have a marked alkalogenic effect upon the acid-base balance which could be advantageous in acidoses but not in metabolic alkaloses. Quite surprising was the increase of $\mathrm{Hb}$ levels without substantial changes in hematocrit and erythrocyte values proceeding in spite of the decrease of a significant $\mathrm{Hb}$ component, i.e. copper (iron not followed). It is possible that a part of elements mobilized by EDTACAL was used for $\mathrm{Hb}$. The decrease in leukocyte count could be accounted for by the restriction of mitoses, DNA and RNA synthesis and of lymphocyte proteins as reported by Chester (1974) after the administration of EDTA or by the deficiency of $\mathrm{Zn}$ which is important for leukocytes. It is, however, necessary to admit that in connection with the presented factors the decrease of leukocyte count was unrealistically rapid.

The finding that the EDTACAL treatment stabilized some parameters, decreased individual variations and differences among animals, not only when deficiency values were reached but also the parameters in the physiological range, are interesting. The question remains whether this phenomenon should be regarded positively as the stabilization of metabolism and a higher resistance to metabolic insults and changes or negatively (reduced reactivity and flexibility of various metabolic and regulation systems, particularly enzymatic and hormonal). Our experiments were carried out on clinically healthy animals. Under pathological conditions the effect of EDTA could be in some respects stronger and in others less pronounced or even of a completely different character. More detailed experiments will be necessary to elucidate the EDTA 
biological activity. It follows from presented results that the effect of EDTACAL is yery complex and that it can influence various metabolic processes, being itself back-influenced depending on circumstances. When the preparations of EDTA type are experimentally or therapeutically applied these more general interrelations should be taken into consideration. A number of experimental or therapeutical applications of these substances in various fields of metabolism are thus offered.

\section{Vliv aplikace Edtacalu Spofa na hodnoty některých biochemických a hemạtologických ukazatelů v krvi ovcí}

U 5 klinicky zdravých ovcí plemene kavkazské merino byl sledován vliv aplikace EDTACALU Spofa v dávce $40 \mathrm{mg} . \mathrm{kg}^{-1}$ ž. h. $1 \times$ denně po dobu 5 dní i. v. na hodnoty 23 biochemických a hematologických ukazatelů v krvi. Edtakalová kůra vyvolala prùkazný $(P<0,05$ až $<0,01$ ) vzestup hodnot močoviny, glukózy, hořčíku ( $u$ tohoto dokonce $\mathrm{z}$ hodnot původrě hypomagnezemických), $\mathrm{pH}$ krve, BE, SB, BB, a naopak průkazný pokles hladin zinku (až na hodnoty subnormální), mědi, počtu leukocytů, aktivity GMT, dále statisticky nevýznamný vzestup hodnot sodíku, draslíku, anorganického fosforu, $\mathrm{Hb}, \%$ methemoglobinu a nevýznamný pokles vápníku, cholesterolu, HK, počtu erytrocytů, aktivity AST, později i hladin sodíku, na hranici průkaznosti byl vzestup hodnot $\mathrm{pCO}_{2}$, nevýrazné změny byly zaznamenány u celkové bílkoviny. Po zahájení aplikace preparátu se začaly hodnoty močoviny, sodíku, hořčíku, zinku, mědi, $\mathrm{pH}$ krve, aktivity GMT a počtu leukocytů měnit již za 24 hodin, u $\mathrm{pCO}_{2}, \mathrm{BE}$, SB a BB po 2 dnech, u Hb za 3.dny, u glukózy za 4 dny, aktivita AST poklesla až po ukončení aplikace. Návrat $\mathrm{k}$ výchozím hodnotám nastával $\mathrm{u}$ většiny ukazatelů postupně po $2-5$ dní po ukončení aplikace, pouze u GMT, pH krve a počtu leukocytů přetrvávaly změny nadále po dalších 5 dní sledování. Na acidobasickou rovnováhu působil EDTACAL alkalogenně. Stabilizoval také některé ukazatele zmenšením individuálních denních výkyvů (močovina, sodík, vápník, hořčík, zinek měd, hemoglobin, eratrocyty, leukocyty), nivelisoval i rozdíly mezi jednotlivými zvíraty (močovina, glukosa, sodík, vápník, zinek, erytrocyty, leukocyty). Účinek EDTACALU se tedy projevil širším zásahem do různých úsekủ metabolismu pokusných zvírat.

\section{Влияние введения ЭДТАКАЛА Спофа на величины некоторых биохимических . и гематологических показателей в крови овец}

У пяти клинически здоровых овец племени кавказский меринос прово;ились исследования влияния введения ЭДКАТАЛА Спофа дозой 40 мг.кг ${ }^{-1}$ живого веса раз в сутки в течение 5 суток внутривенно на величины 23 биохимических и гематологических показателей в крови. Эдкаталовый курс лечения вызвал убедительное $(\mathrm{P}<0,05<0,01)$ увеличение вели"чин мочевины, глюкозы, магния (в данном случае с первоначальных гипомагниевых величин), рН крови, BE, SB, BE и, наоборот, убедительное понижение уровня цинка (до величин ниже нормы), меди, численности лейкоцитов, активности С МТ, статистически незначимое увеличение величин натрия, калия, неорганического фосфора, Нb, процента метемоглобина, незначительное понижение кальция, холестерина, НК, числа эритроцитов, активности AST, позже также уровней натрия. На пределе доказательности находилось увеличение величин $\mathrm{pCO}_{2}$, несущественные изменения были установлены у общих белков. После начала ввода пре- 
парата величины мочевины, натрия, магния, цинка, меди, рН крови, активности СТМ и числа лейкоцитов менялись уже через 1 сутки, величины $\mathrm{pCO}_{2}, \mathrm{BE}, \mathrm{SB}$ и ВВ после 2 суток, Нb - через 3 суток, глюкозы - через 4 суток, активность AST понизилась только после завершения введения. Возвращение к исходным величинам у болышинства показателей наступало постепенно до 2-5 суток после окончания введения препарата, только у СТМ, рН крови и числа лейкоцитов величины оставались без изменений в течение следующих 5 суток наблюдения. ЭДТАКАЛ оказывал алкалогенное воздействие на кислотно-основное равновесие. Он стабилизировал также некоторые показатели уменышением индивидуалыных суточных отклонений (мочевина, натрий, кальций, магний, цинк, медь, гемоглобин, эритроциты, лейкоциты), нивелизировал тоже разницу между отдельными животными (мочевина, глюкоза, натрий, кальций, цинк, эритроциты, лейкоциты). Следовательно, действие ЭДТАКАЛА проявилось более существенным вмешательством в разные области метаболизма подопытных животных.

\section{References}

BARTÍK, M. - PJSKAČ, A. et al.: Veterinární toxikologie. SZN Praha, 1974, 304 p.

CHESTER, J. K.: Biochemical function of zinc with emphasis on nucleid acid metabolism and cell division. Proc. II. Internat. Symp. Trace elements metabolism in animals, University Park Press, Baltimore-London-Tokyo, 1974: 39-50.

CHRISTOPHER, J. P. - HEGENAUER, J. C. - SALTMAN, P. D.: Iron metabolism as a function of chelation. Proc. II. Internat. Symp. Trace elements metabolism in animals, University Park Press, Balt!more-London-Tokyo, 1974: 133-145.

DANIEL, R. C. W.: Induced hypocalcaemia in cows and sheep. II. Changes in plasma potassium levels. Brit. Vet. J., 136, 1980: 45-50.

DANIEL, R. C. W.: Induced hypocalcaemia in cows and sheep. III. Changes in plasma magnesium levels. Brit. Vet. J., 136, 1980: $51-56$.

GDOVIN, T. et al.: Vnútorné choroby hovädzieho dobytka, oviec, kôz a ošípaných. Príroda, Bratislava, 1970, $628 \mathrm{p}$.

HAUSCHILD, F.: Pharmakologie und Grundlagen der Toxikologie. VEB Georg Thieme Verl., Leipzig, 1961, $1162 \mathrm{p}$.

HIEPE, T.: Schafkrankheiten. VEB G. Fischer Verl., Jena, 1970, 362 str.

HILL, R. - SMITH, I. M.: The influence of iron, copper, zinc and EDTA on fowl typhoid in chicks. Proc. II. Internat. Symp. Trace elements metabolism in animals. University Park Press, Baltimore-London-Tokyo, 1974; 641-643.

KLEAVY, L. M.: Interactions among dietary copper, zinc and the metabolism of cholesterol and fosfolipids. Proc. II. Internat. Symp. Trace elements metabolism in animals, Baltimore-London-Tokyo, 1974: 527-529.

KIRCHGESSNER, M. - ROTH, H. P.: Bestimmung der Verfügbarkeit von Zink im Stoffwechsel sowie Ermittlung des Zinkbedarfs mittels Aktivitätsänderungen von Zink-Metalloenzymen. Arch. Tierernährung, 25, 1975: 83-92.

KRATZER, F. M.: Zinc, iron and chelate interactions in poults and chick. Proc. II. Internat. Symp. Trace elements metabolism in animals. University Press, Baltimore-London-Tokyo, 1974: $527-529$.

LANTZSCH, H. J. - MENKE, K. H.: Effect of parenterally administered EDTA on endogenous secretion and metabolism of zinc in the rat. Proc. II. Internat. Symp. Trace elements metabolism in animals. University Park Presse, Baltimore-London-Tokyo, 1974: 530-533.

NOURANNE, P.: On the effect of food magnesium level on the activity of BASP, ALAT and LD in pig serum. Nord. Veter. Med., 30, 1978: 74-82.

PETERS, H. A.: Trace mineral metabolism in porphyria and other neuropsychiatric conditions. Role of chelation therapy. Proc. II. Internat. Symp. Trace elements metabolism in animals. University Park Press, Baltimore-London-Tokyo, 1974: 682-683.

PORIES, W. J. - MANSOUR, E. G. - PLECHA, F. R. - FLYNN, A. - STRAIN, W. H.: Inhibition of biological action of zinc in man body by other trace elements. Proc. II. Internat. Symp. Trace elements metabolism in animals. University Park Press, Baltimore-London-Tokyo, 1974: $656-658$. 
POTEL, K.: Lehrbuch der pathologischen Physiologie der Haustiere. VEB Gustav Fischer Verl., Jena, 1969, $874 \mathrm{p}$.

REITZ, R. E. - WEINSTEIN, R. L.: Parathyroid hormone reaction in familial vitamin D resistent rickets. Proc. Internat. Symp. on Clinical Aspects of Metabolic Bone Diseases. Excerpta Medica, Amsterdam 1973: 407-412.

ROTH, P. - KIRCHGESSNER, M.: Zinc-metalloenzyme activities in response to depletion and repletion of zinc. Proc. II. Internat. Symp. Trace elements metabolism in animals. University Park Press, Baltimore-London-Tokyo, 1974: 509-512.

SCOTT, D. - BEASTALL, G.: The effect of intravenous phosphate loading on salivary phosphate secretion and plasma parathyroid hormone levels in the sheep. Quart. J. exper. Physiol., 63, 1978: $147-156$.

SOELI, N. E. - FROESLIE, A. - AASETH, J.: The mobilisation of copper in sheep by chelating agens. Acta Veter. Scand., 19, 1978: 422-429.

ŠPAK, G. E.: Soderžanije cinka $i$ aktivnost' ugobnoj angydrazy $v$ krovi sel'skochozjastvennych životnych. Leningradskij Veter. Inst. Sb. raat 46, 1976: $71-74$.

VIŠNJAKOVA, S. I.: Obezvoživanie organizma i preraspredelenie elektrolitov v krovi životnych. Voroněžskij selsk. chozj. Inst. imeni K. D. Glinki, Nauč. trudy, 70, 1975: 188-242.

VODRÁZKA, J. - MOZGOV, I. J. - ŠIMƯNEK, J:: Veterinárná farmakológia. Príroda, Bratislava, 1980, $435 \mathrm{p}$.

WENKE, M. - HYNIE, S. - MRÁZ, M.: Farmakologie. Avicenum, Praha, 1977, 499 p. 